\title{
Young People: Between Literature and Advanced Technologies
}

\section{Ahmad Idris Asmaradhani}

How to cite : Asmaradhani, A., I., 2018 Young People: Between Literature and Advanced Technologies Journal of Language Learning and Research. 1(1). 1-11. https://doi.org/10.22236/jollar.v1i1.1239

To link to this article: https://doi.org/10.22236/jollar.v1i1.1239

(C)2021. The Author(s). This open access

2 article is distributed under a Creative

Commons Attribution (CC BY-SA) 4.0

license.

曲 Published Online on 11 Maret 2020

\begin{tabular}{l}
\hline Submit your paper to this journal \\
\hline CrossMark \\
\hline
\end{tabular}




\title{
Young People: Between Literature and Advanced Technologies
}

\author{
Ahmad Idris Asmaradhani $\triangle$
}

\begin{abstract}
In the eyes of literature, existentialist thinkers focus on the question of concrete human existence and the conditions of this existence rather than hypothesizing a human essence, stressing that the human essence is determined through life choices. The ideal, however, is that humans exist in a state of distance from the world that they nonetheless remain in the midst of. This distance is what enables humans to project meaning into the disinterested world of in-itselfs. This projected meaning remains fragile, constantly facing breakdown for any reason from a tragedy to a particularly insightful moment. In such a breakdown, humans are put face to face with the naked meaninglessness of the world, and the results can be devastating. It is porposed that literature and the media combined have a powerful impact on those who wish to truly realize and understand their message. By studying, reading, learning, experiencing, and knowing the culture of the present and those cultures of the past then one can understand the ideas of life and how the two work together to help us better understand each other and ourselves. In what ways our present culture, our technological advances, and the media shape who we are as individuals is not a simple question. The answer seems to elusively hide in a world filled with cultural complexities. But, it is no secret to find that literature is a source of power. It does influence, guide, and shape the human become as they continue their journey through life. Hence, since human are never without the influence of literature, they will always have factors working to modify the human being. However, it is their choice as to how they internalize what they are exposed to, and in turn, it is up to them to determine the individual that ultimately prevails.
\end{abstract}

Keywords: play, influence, mental illness

Universitas Muhammadiyah Surabaya 


\begin{abstract}
Di mata sastra, pemikir eksistensialis memusatkan perhatian pada pertanyaan tentang keberadaan manusia yang konkret dan kondisi eksistensi ini daripada menghipotesiskan esensi manusia, yang menekankan bahwa esensi manusia ditentukan melalui pilihan hidup. Yang ideal, bagaimanapun, adalah bahwa manusia ada dalam jarak yang jauh dari dunia bahwa mereka tetap berada di tengah-tengahnya. Jarak ini memungkinkan manusia memproyeksikan makna ke dalam dunia yang tidak tertarik. Makna yang diproyeksikan ini tetap rapuh, terus- menerus menghadapi kerusakan karena alasan apapun - dari sebuah tragedi sampai saat yang sangat mendalam. Dalam keadaan seperti itu, manusia berhadapan langsung dengan ketidakberdayaan duniawi, dan hasilnya bisa sangat menghancurkan. Hal ini menunjukkan bahwa literatur dan media digabungkan memiliki dampak yang kuat pada mereka yang ingin benar-benar menyadari dan memahami pesan mereka. Dengan belajar, membaca, belajar, mengalami, dan mengetahui budaya masa kini dan budaya masa lalu, seseorang dapat memahami gagasan hidup dan bagaimana keduanya bekerja sama untuk membantu kita lebih memahami satu sama lain dan diri kita sendiri. Dengan cara apa budaya kita saat ini, kemajuan teknologi kita, dan bentuk media siapa kita sebagai individu bukanlah pertanyaan sederhana. Jawabannya tampaknya melayang-layang di dunia yang penuh dengan kompleksitas budaya. Tapi, bukan rahasia lagi untuk menemukan bahwa sastra adalah sumber kekuatan. Ini mempengaruhi, membimbing, dan membentuk manusia menjadi saat mereka melanjutkan perjalanan mereka melalui kehidupan. Oleh karena itu, karena manusia tidak pernah tanpa pengaruh sastra, mereka akan selalu memiliki faktor-faktor yang bekerja untuk memodifikasi manusia. Namun, inilah pilihan mereka bagaimana mereka menginternalisasi apa yang mereka hadapi, dan pada gilirannya, terserah pada mereka untuk menentukan individu yang pada akhirnya menang.
\end{abstract}

Kata kunci: bermain, pengaruh, penyakit jiwa.

\title{
Correspoonding author: deossa123@yahoo.com
}

\section{(1) (2) 2021. The Author(s). This open access article is distributed under a Creative Commons} Attribution (CC BY-SA) 4.0 license. 


\section{INTRODUCTION}

In her book, Using Literature to Help Troubled Teenagers Cope with Health Issues, Bowman (2000) states that today, traditional illnesses and high risk behaviors of adolescents have become interrelated through the multitude of physical, social and emotional changes young people experience. As one of the solution, she suggests that teenagers read or be taught "good" literature. She reasons that good literature gives adolescents the truth has incredible power to heal and to renew. Bowman continues that good lieterature can function as the reference resource provides a link for teachers, media specialists, parents, and other adults to those novels that can help adolescents struggling with health issues It has been the topic of various discussions that through the fictional characters, literature provides guidance on encouraging young people to cope while improving their understanding about some certain behavior related problems such as depression, alcoholism, and eating disorders. All of these issues and others are examined from both a literary and psychological perspective in the resources they read, discuss, and even experience by role playing. It is expected that through the selected good lieteture resources, young people will in turn "define" the central character's struggle in issues and grow some understanding in response to the character's difficulties. In the end, the message in the resources will give readers insight into helping their selves with similar problems. The message in the resources can even provide the tools with which the young people address their own problems.

There is no objection that young people who have good insight into their own difficulties, including a realistic assessment of their own contribution and the contribution of others to those difficulties, are more likely to be to use Maclean's term resilient (2004). That is to say that young people who are able to recognize benefits, as well as negative effects, from severe adversity are likely to be resilient. Insight helps people to take appropriate actions and make appropriate choices. It is therefore linked to self-efficacy and to initiative.

Similarly, there is an increasing amount of research and practice literature on how resilience can be built. Some researches are related specifically to looked after children but much of it are more related to young people in adverse circumstances. Quoting the view of Richman, Rosenfeld and Hardy (1993) Maclean states that lietarture in various resources can help young people through: (1) Listening just listening, not advising or judging; (2) emotion that is helping by evaluating the attitudes, values and feelings; (3) reality confirmation sharing the perspective of the world; (4) task appreciation; (5) task challenge challenging, stretching, motivating; (6) tangible assistance in the forms of money or gifts; and (7) personal assistance that is driving young people somewhere. 
Maclean also suggests that in order for children to receive social support, develop trust, develop attachments, and build a positive identity they need to remain connected to key figures in their lives. This in Maclean's view will often include parents, step parents, siblings, grandparents, aunts, uncles, cousins, godparents, close friends, neighbours, past carers, past teachers, and past youth leaders. Figures to be discussed in this paper, however, are not the ones as mentioned suggested by Mclean above. Instead, they are figures found in any literary resources both protagonists and antagonists with all conflicts, problems, and other circumstances faced and how they solve their own conflicts and problems. It is from these figures, in the forms of characters, with their conflicts and problems as well as all of their circumstances that will be taken into consideration why literature is important supplement for young people to consume.

On the basis of the above background, the issue in this paper is addressed to explain three major points: (1) why young people should learn from literature; (2) why it is drama; and how advances in technology affect the young people. Discussed in terms of theoretical statements proposed by some lietarary theorists, this paper is also intended to describe that today's young people are more vulnarable to mental disease in many forms that are unavoidably and most of the times caused by some advances in technology and their consumtive behaviors.

\section{SOME THEORETICAL FACTS}

When young people, just like the older one, are stumbled with their psychological problems, they will usually try to find a way to solve them. Some however, will seek helps from others. Most of those who try to seek helps are young people do not know what their problems are, which consequently, they do not know either where to seek helps.

In relation to such situation, it is suggestable to refer to the term extentialism as proposed by Kierkegaard (see: Wikimedia, 2012). Existentialism is a term applied to a school of 19th and 20th century philosophers who share the belief that philosophical thinking begins with the human subject. That is, it is not merely the thinking subject. Instead it involves the acting, feeling, and the living human individual. In existentialism, the individual's starting point is characterized by what has been called "the existential attitude", or a sense of disorientation and confusion in the face of an apparently meaningless or absurd world. Many existentialists have also regarded traditional systematic or academic philosophies, in both style and content, as too abstract and remote from concrete human experience. 
In the above statements, there are some key points to note in relation to extetialism. They are: acting, feeling, living, and most importantly abstract. Kierkegaard who is widely regarded as the father of existentialism maintains that the individual is solely responsible for giving his or her own life meaning and for living the life passionately and sincerely, in spite of the obstacles and distractions. The obstacles and distractions include despair, angst, absurdity, alienation, and boredom. It is necessary to reassert that while many young people do not know what their problems are, many more others seek helps. In this paper, therefore, the framework maintains that help-seeking is a process of translating the very personal domain of psychological distress to the interpersonal domain of seeking help. The factors that are common in young people are, in some and the other ways, facilitating the solution. In some other ways, however, such factors are inhibiting this translation process. These included factors that determine awareness of the personal domain of psychological distress and that affect the ability to articulate or express this personal domain to others, as well as willingness to disclose mental health issues to other people.

\section{Why Literature and Why Plays}

Literature is as many experts say a form of art. As a form of art one very, if not most, important part of it is the beuty. In relation to this, Prasad (2005), quoting Franz Cizek's statement, states that, "The most beautiful things in the creations of the child are his 'mistakes'. The more a child's work is full of these individual mistakes, the more wonderful it is. And the more a teacher removes them from the child's work, the duller, more desolate and impersonal it becomes".

In Prasad's view, it is neither sufficient nor justified to consider only the adult's approach in planning educational programmes for children, for the one who is at the receiving end is not an adult. The child's approach is very, if not entirely, different from that of the adult. Hence, in Prasad's view, for good educational planning it is essential to take it into account. Prasad continues that children do not give consideration to the end result of anything that they do or like to do, unless they have experienced its results first-hand. Unlike the adult, the child does not have any value system governing his thinking and action. If there is anything a child considers desirable, it is based on the elements of joy, satisfaction, accomplishment, recognition, and the argument behind the question: "If you can do it, why can't I?" Prasad also sees that there is another element that plays an important role in this respect. It is, in his opinion, the wish to be like adults not in every respect, but in selective matters, such as those which will allow their spirit of adventure to be satisfied. 
Literary works are protrait of the real life as well as the real nature. Some, if not most, of school literary works are designed to tap the rich resource of students' literature to stimulate discussion of many things. Some even designed to direct the students' attention to see the violence around them, and ultimately, to direct them find the peaceful ways to resolve conflict. The most important is that issues of violent and nonviolent conflict resolution are clearly presented so that students can examine the following general questions:

- What is conflict?

- What is violence?

- What are some causes of violence?

- What are some consequences of violence?

- What alternatives to violence can be used when conflicts need to be settled?

- How can people prevent violence?

Literature is particularly helpful in discussing such issues, not only by describing conflicts, but also by indicating why the conflict occurred and what followed in its aftermath. A novel or short story might show the anger that led to violence, and the fear, unhappiness, hurt, and despair that violence can leave in its wake. Because literature is often dramatic, it can strike an emotional chord that holds student interest while it broadens perspective and heightens awareness of one's own and other's feelings and beliefs.

Using literature for this purpose can, in turn, awake an interest of the young people in literature itself. The most important criterion used in choosing the resource (books), thereforte, is that they model the qualities of "good" literature. That is to say that it is a resource where the author uses language beautifully, develops sensitivity, believable characterization, and in well-crafted plots. These criteria might difficult to put forwrd. But as Letwin (2011) suggests, they are meant to present examples of what is available and how, with appropriate teacher guidance, literature can be used to shed light on various topics. For such reason Letwin suggests the selections of resources include some examples of discussion questions or topics. These kinds of questions, adapted to meet the needs of diffrent needs to adjust different psychological prblems faced by the young people.

Meantime, plays are considered more suitable resource as play is the genre of literature containing "actions" that requires the reader in this case young people involved both mentally and physically. In teaching-learning process, involving classroom activities are essential in helping students learn the analytic, policy making, evaluative, and participatory skills young people need to help solve their own and other societal problems. In some few instances suggestions for such activities are included in the resource books but in most cases they are 
left to the discretion of the teacher.

In his article "Nurturing Social and Emotional Development in Gifted Teenagers Through Young Adult Literature" Herbert and Kent (2011) state that young adult literature serves as an effective strategy to address emotional issues in the lives of gifted teenagers.

They reason that gifted young adults are often highly sensitive and very aware of their feelings. Gifted young people, in their view, can also be intense in their depth of feeling, and they exhibit a heightened level of sensitivity, an intensity, or emotional overexcitability that needs supportive adults who view these characteristics positively and have a clear under-standing of their frustrations and anxiety. He also state that teachers who work with gifted youngsters, of course, also need practical classroom strategies to address these students' feelings and to create supportive environments where students feel comfortable expressing how they feel.

Besides, plays can seen as a form of literature with common emotional concerns in it. Emotional upheavals experienced by sensitive young people are often overwhelming and, therefore, using appropriate plays may serve as a catalyst in getting young people through their hurt, to find some answers. In addition to the reader's initial response, the therapeutic effect also depends on the group discussion facilitated by the teacher who provides follow-up techniques such as reflective writing, role-playing, creative problem solving, music and art activities, or self-selected options to pursue individual needs. Presented in this way, drama can be enjoyable while providing a time for solid introspection for young people.

Furthermore, plays provide insights about the life of the characters. It is through the charcaters and the characterization that the young people will understand the feelings of others. Understanding that others have similar feelings will in turn help young people form friendships, is an important concern during adolescent development. This particular advantage must be underlined by the teacher. When necessary, teachers can select topics involving friendships and make them the focus of the sessions, then ask the students to pay closer attention. The teacher can then move the activity into role-playing, which is intended to make the young people experience the different feelings. In this way, teachers can also have the opportunity to look deeply at a variety of issues with their students. 
When discussing about "Why Teach Drama?" (1985), Buchanan states that teachers and parents often don't really understand what a classroom drama (or play) teacher does, and they can question the importance of drama class, especially since most classroom teachers feel pressured to get through a given curriculum in a given time. Drama class in his view can shortens the classroom teacher's contact time. He and his colleagues who work in drama-classes with and for young people know instinctively that it is important, but he and his colleagues are not always easily able to communicate this understanding. From this statement by Buchanan, one can see that there are a lot of advantages that both the teacher and the students can take.

In another part, Buchanan also states that the future of one's nation depends on the ability to create-and to be creative. He further states that during the coming decades, the most important national resources will be human resources. If one's nation is to continue to meet the challenges of the future, today's schools (where young people learn) need to develop creative leaders. In reasoning for invloving the students by role playing, Buchanan quotes Chinese proverbs as follows:

"Tell me and I will forget.

Show me and I will

remember.

Involve me and I will understand."

From the above Buchanan's statements, one can see that involving young people by role-playing will make it possible to make young people in other people's feet. That is, by making them act as in drama, they will experience how other feel.

Plays or dramas are important means of stimulating creativity in problem solving. It can challange the young people's perceptions about their world as well as about themselves. Exploring things through drama can provide students with an outlet for emotions, thoughts, and dreams that they might not otherwise have means to express. Even only within a short time experiencing moments by becoming another, young people will have a chance to explore a new role, try out and experiment with various personal choices and solutions to very real problems; problems from their own life, or problems faced by characters in literature or historical figures. As Buchanan suggests, the most important of all is that young people do all of these in a safe atmosphere, where actions and consequences can be examined, discussed, and in a very real sense experienced without the dangers and pitfalls that such experimentation would obviously lead to in the "real" world. This is perhaps in Buchanan's view the most important reason (1985). 
It is nothing new that young people not very different from that of children are always looking for new experiences all the time, and want to examine and put everything to test that attracts their eyes or feelings. If they like the experience, they want to repeat it, until something new catches their attention and seems to be interesting or challenging. The things that the young people get attracted to are sometimes those that adults either do not see or are not interested in. Often, however, they want to experience the things just like what the adults do. In short, there are two different worlds one is that of the adults and the other is that of the young people. It is this difference that makes the young people are eager to experience.

\section{The Effects of the Media}

Whether every old or young feels it or not, media just like literature influences the life of individual. Most individuals, as it can be seen, just do not fully realize it yet. Every individual experience it with every waking moment and every action and reaction they experience within life. The case is that, it is necessary to explain how it influences life, how it constructs life, and how it molds life into the guiding force. To be clearer, one may post a question like, "In what ways does our present technological advances and the media shape who the old and the young as individuals?

In the above discussion (2.1), it can be seen that it is no secret to find that literature is a source of power. It does influence, guide, and shape the people human being become as human continue the "journey" through life. Hence, since human are never without the influence of literature, human will always have factors working to modify the kind of people they are. However, again, it is their choice as to how they internalize what they are exposed to, and in turn, it is up to them to determine the individual that ultimately prevails. If literature does something to human being, then, How does the media actually control who people especially young people are and what they become?

According to a note from University of Miami (Ann, 2010), the average individual rests his or her eyes on an estimated 3,000 discrete ads in every-day. With such a strong media force present within life journey, the note asks, "how can we claim to be uninfluenced?" The answer is, of course, No, we can't. The next question the note ask is, "Do we really know what message we are being sold, and at what price we are choosing to pay?" The media according to the note sells us an idea or an image. Clearly, they sell us an ideology we are quick to attach ourselves to and, in essence, become. Therefore, the note asks, Are we as human's mere products of the cultural world within which we live?" 
It is no question that every individual lives in a world of constant consumption. But, what it is that every individual is really buying? When a boy or a girl searches through the latest model of a pair of pants or a blouse to find the perfect outfit to wear advertise by the media, he or she will always finds it, orders it, and puts it on. When the new model does not make him or her feel any better like a new man or a new woman he or she is disappointed. After twice or even several times of disappoinments, young people begins to realize that they were not simply buying the pants or the blouse they saw on the media. Instead, they were buying the glamour, the feeling, and the biggest part of it all the confidence. They were buying a personal image.

Such kind of thing can be seen alive and well all around young people in theri every-day life. Thus, it is not easy to get away from such media. In every campus, it is easy to find students drive luxorious cars and wear expensive dresses with black berries in hands. In short, it is hard to deny the product young people have become, formed by the media within which they live.

Media has a powerful impact not only on young people but also on the old ones. It is very crucial, therefore, to reconsider the distinction between the term "want" and "need" for those who wish to truly realize and understand their message. By studying, reading, learning, experiencing, feeling, and knowing culture of the present and those cultures of the past. Only then can one understand the ideas of life, which then may help every individual better understand the concepts of happy life they have to pursue.

\section{CONCLUSION}

So far in the discussion, it is proven that both literature and media can influence the emotions and offer some certain effects on a person. It is not necessary to give each of them the precentages. If media can influence the way a person dress in the models offered by the media literature can also affect how the same person dress like the character in the drama. Similarly, if someone who listens to heavy metals will dress outraged and may wear nose rings, literature can also make the same listener behave in the same way. The difference is that young people who take part in plays will experience the same things they had to role just before they really behave. In this way, they have experienced things before they really do the things. This experiencing things before doing things will make them reconsider what they really wish to do. And this is because the have been in other people's shoes. 
Literature especially plays serve young in four major ways: it helps them to better understand themselves, others, their world, and the aesthetic values of written language. When young people read fiction, narrative poetry, or biography, they often assume the role of one of the characters. Through that character's thoughts, words, and actions the young people develop insights into their own character and values. After some frequent role playing, because of experiences with literature, young people will mode their behavior and value structures are changed, modified, or extended. By exploring life in this way as Barbara states they will in turn come to better understand the world in which they live and their own relationship to it.

\section{REFERENCES}

Ann. 2010. Life and Literature. Ohio: Miami University,. Retrieved from: http://www.units.muohio.edu/englishtech/eng49501/groffsc/engmedia.html -------. Extentialism. 2012. UK: Wikimedia Foundation, Inc.,. Retrieved from: http://en.wikipedia.org/wiki/Existentialism

Bowman, Cythia (Ed.). 2000. Using Literature to Help Troubled Teenagers Cope with Health Issues. London: The Greenwood Press.

Buchanan, Matt. "From Performing together: The Arts and Education". USA: The American

Association of School Administrators, The Alliance for Education and The John F. Kennedy Center for the Performing Arts in 1985. Retrieved from: http://www.childdrama.com/why.html

Herbert, Thomas P. and Richard Kent. "Nurturing Social and Emotional Development in Gifted Teenagers Through Young Adult Literature. 2011. New York: Supporting Emotional Needs of the Gifted,. Retrieved from: http://www.sengifted.org/archives/articles

Kiefer, Barbara. 2012. Children's Literature: History, Literature in the Lives of Children, Environment, Awards. USA: Net Industries and Its Licensors,. Retrieved from: http://education.stateuniversity.com/pages/1829/ChildrensLiterature.html

Letwin, Alita Zurav. 2011. Literature for Children and Young Adults: Examining Issues of Violence and Conflict Resolution". USA: Center for Civic Education,. Retrieved from: http://new.civiced.org/resources/publications/

Maclean, Kirstie. 2004. Resilience: What it is and how children and young people can be helped to develop it". CYC-Online Issue 62. http://www.cyc- net.org/cyc-online/cycol-0304-resilience.html

Prasad, Devi and Krishna Kumar. 2005. Education for Living Creatively and Peacefully. India: NCERT. 